\title{
Family in Polish jokes
}

\author{
Dorota Brzozowska
}

\begin{abstract}
The main aim of the research is to describe the image of family life presented in post-socialist jokelore. Contemporary material (from the late 1990s till the present day) consisting of jokes published in books, booklets, newspapers and on the Internet was collected and analysed for this study, altogether 600 jokes. As there is no special cycle of jokes connected with family life, texts of different series were taken into account in which the words "woman", "man", "child" or their synonyms were present. The results show that there exists a number of stable targets, e.g. aggressive mothers-in-law or adulterous wives. New targets are reluctant to arise: there are no jokes about the paternal leave which was recently introduced and widely discussed in the media, and there are also no jokes about women drinking alcohol, although this problem exists in the society which gives more and more permission to women drinking in public places. We can conclude on the basis of this research that family jokes do not deal with current and topical issues; instead, they have remained mostly traditional with certain recurring cycles being at the core of the Polish cultural heritage.
\end{abstract}

Keywords: Polish family jokes, nuclear family, stereotypes about women, postsocialist jokelore

\section{Introduction}

The aim of the paper is to show aspects of gender issues present in Polish jokes ${ }^{1}$ about women, men and children. These targets most often occur in the private sphere.

1 A joke is "a short narrative-dialogical text, which ends with a punch line and is meant to cause laughter" (Raskin 1985: 81). On the semantic level it consists of at least two opposite scripts. A script is "a large chunk of semantic information surrounding the word or evoked by it. A text can be characterised as a single-joke-carrying text if both of the following conditions are satisfied: 1) the text is compatible, fully or in part, with two different scripts; 2 ) the two scripts with which the text is compatible are opposite" (ibid.). 
Polish family in jokes is represented in most cases as nuclear - it consists of a mother, father and usually son by the name of Jasio or Kazio. Polish women are presented as wives, very often adulterous, while the men are drunkards not caring about their children and not interested in domestic chores. Children are cleverer than their parents and teachers. Sometimes mothers-in-law - grandmas - interfere with the family. In more recent jokes, the stable and traditional world of men versus women is changed as gender issues are being discussed from the feminist point of view.

For the sake of this paper, contemporary material (from the late nineties ${ }^{2}$ till the present) consisting of jokes published in books, booklets, newspapers and on the Internet was collected. As there is no special cycle of jokes connected with family life, texts of different series were taken into account in which the words "woman", "man", "child" or their synonyms were present. Six hundred jokes were analysed altogether - two hundred from each of the three categories. The main aim of the research was to check what picture of family life is presented in the post-socialist jokelore as these jokes appeared in the years when the economic and political situation stabilised and the quality of life had become quite satisfactory.

The question I am interested in is how the spheres of the public and the private are depicted in jokes, in which way they are similar to the stereotypical roles of men and women in the society (see Jędrzejko 1994), and to what extent the patriarchal world view is still evoked as it used to be in older, pre-1990 jokes.

\section{Marriage}

The most numerous group of jokes (about 30\%) shows women as wives. This is a role that carries a number of entrenched stereotypes about women as opposed to men. "The existence of a female and male stereotype is conspicuous and plays a meaningful role amongst social beliefs of the human being [...]. Stereotypically women are seen as warm and expressive, whereas men as rational and effective in their deeds" (Nęcki 2000). The script of ADULTERY is the most popular one.

"Styszałem, że twoja żona zaliczyła całe miasto?"

"Też mi miasto, pięć tysięcy mieszkańców."

"I have heard that your wife has slept with the entire city?"

"Five thousand people - you call that a city?!"

(Ale jaja. O kobietach 12/97)

2 Cf. Brzozowska 2003. 
Not only Polish women are presented as unfaithful wives but also their husbands have extramarital affairs:

“Tato,” zali się córka Kowalskiemu, "mąż mnie zdradza. Co mam robić?” "Poczekaj na mamę, ona ma większe doświadczenie w tej sprawie."

"Daddy," complains Kowalski's daughter, "my husband cheats on me, what shall I do?"

"Ask your mother, she's got more experience in this matter."

(Świeże dowcipy. O kelnerach 7/97)

Many of the examined jokes have mistresses as their butts, and there is also a significant number of jokes about DIVORCE. Those two subjects are closely related because in real life most couples usually consider infidelity as the main reason for their divorce.

Nowadays women have more opportunities to abandon an unsatisfactory marriage than several decades ago. Statistically, women are the ones who are more often unhappy in their marriages and are petitioners in most (70\%) of divorce cases $^{3}$. The divorce rate has been growing rapidly and although the prevailing percentage of all marriages take place in church and divorces are not allowed in the Roman Catholic Church, which is the main religion in Poland, the number of marriages falling apart is still growing.

“Czy jest pan rozwiedziony?”

"Jeszcze nie."

"Are you divorced, sir?"

"Not yet."

(Coś z dowcipami. O facetach 11/97)

Sometimes a marriage lasts much longer than the spouses would wish. Another script in Polish jokes is the one concerning dead wives who are a "pain in the neck" for their still living husbands:

“Nie płacz, czyżbyś nie wierzyt, że spotkasz się ze swoją żoną w niebie?!” pociesza przyjaciel wdowca.

"Wierzę i dlatego płaczę!"

"Don't cry, don't you believe you will meet your wife in Heaven?!” a friend consoles the widower.

"I believe I will, and that's why I am crying!"

(Dowcip za dychę 6-7/94)

${ }^{3}$ Legal advice portal, http://www.prawnik-online.eu/porady-prawne/najnowsze-statystyki-dotyczace-rozwodow, last accessed on 2 June 2012. 
On the other hand, according to statistics, a man who becomes a widower cannot take proper care of himself and quite often dies shortly after his wife, or wants to find another wife as soon as possible and remarry sooner than the woman in the same situation ${ }^{4}$ (Szukalski 2011). And those facts are referred to in jokes, too:

Po pogrzebie do wdowca podchodzi jego najlepszy przyjaciel $i$ mówi:

"Nie zatamuj się, stary. Za rok, dwa znajdziesz sobie jakąś miłą babkę, która cię pocieszy.”

"Za rok? A co ja będe robit dziś wieczorem?"

After the funeral the best friend approaches the widower and says:

"Don't be so broken-hearted. In a year or two you will find a nice bit of skirt and you will find consolation in her."

"In a year? But what am I going to do tonight?"

(Coś z dowcipami. O facetach 11/97)

\section{Alcohol}

One of the main marital problems is the use of alcohol. It is a frequent theme of jokes in this study. Drunkenness is the male domain in jokes and the reason for numerous domestic quarrels in which a woman tries to convince her husband to stop drinking - unfortunately, usually without results.

Kolega zwierza się Kowalskiemu:

"Moja stara przysięgła, że mnie zostawi, jak nie przestanę pić."

"No i co?"

"No, będzie mi jej brakowato."

A friend confides in Kowalski:

"My wife swore she would leave me if I do not stop drinking."

"And?"

"Well, I am going to miss her."

(www.dowcipy.celebs.pl/pijacy.html)

The "culture of drinking" has changed rapidly in the recent years under the influence of the Western world ${ }^{5}$. It is connected strictly with the higher popularity of beer, the appearance of beer gardens, strong promotion of many different breweries and thousands of new pubs. During the communist times, people

4 Piotr Szukalski; Małżeństwa powtórne w powojennej Polsce, http://www.stat.gov.pl/ cps/rde/xbcr/pts/oz_wiadomosci_statystyczne_4_2011.pdf.

5 http://www.wiadomosci24.pl/artykul/kultura_picia_alkoholu_jak_nas_postrzegaja_ inne_narody_180582-2--1-d.html, last accessed 2011-02-04. 
drank at home, and often it was forbidden homemade alcohol, particularly moonshine vodka that they chose. Beer drinking was connected only with "freebooters" standing near the "beer box", on the social margin.

Every year the sale of weaker types of alcohol in Poland increases, and so does the social awareness of the harmful effects of alcohol drinking ${ }^{6}$. What is interesting is the fact that the social campaigns against drinking, so popular recently, have a strong gender bias. A popular slogan: "You have been drinking - do not drive" addresses men only, which can be seen from the use of the masculine form in the Polish language.

"Tyle się złego naczytałem na temat alkoholu,” mówi Antek do kolegi, “że wreszcie sobie powiedziatem, czas raz na zawsze z tym skończyć!” "Z piciem?" "Nie, z czytaniem."

"I have read so many bad things about alcohol," Antek tells his friend, "that I have promised myself to stop it once and for all!"

"Stop drinking?"

"No, reading."

(Xsiega humoru 1999: 191)

Jokes about alcohol are willingly told in communities with the dominant bachelor-type culture. The Polish culture is a bachelor culture dominated by masculine solidarity and equality where the cult of mates is more important than a family (cf. Davies 1990: 56, where he talks about Australia in a similar context). "Pals" are substitutes and rivals of a family; they talk about sports, cars and women, they go hunting or fishing together. Drinking proves men's equality, solidarity and masculinity, and facilitates their entering into relationships. Following the macho image that "boys do not cry", they are strong, not effusive and not inclined to confide in others. They are allowed to transgress these dictates when they are under the influence of alcohol, which gives them courage to break the stereotype.

The basis for jokes about drunkards is provided by a contradiction between the labour and production values and the hedonistic values of consumption, idleness and feasting. Such texts function in groups in which men are isolated or where men and women perform clearly defined and different roles (Davies 2002). These roles are also unequivocally present in jokes in which a wife usually appears next to her drunkard husband.

6 Statistically Poles drink less alcohol (10.6 liters) than the people in other EU countries (10.85 liters per person over 15 years old). In 2011 it was $3.7 \mathrm{l}$ of strong alcoholic beverages, $6.1 \mathrm{l}$ of beer and $0.4 \mathrm{l}$ of wine per person. See http://www.egospodarka.pl/79723,Spozycie-alkoholu-w-Polsce-nizsze-od-sredniej-UE,1,39,1.html, last accessed on 19 April 2012. 
Przychodzi mąż do domu wieczorem, oczywiście na lekkim cyku. Żona pyta:

"Gdzie byteś?"

"Na szachach."

“To czego śmierdzisz piwem?”

"A czym mam śmierdzieć, szachami?"

A husband comes back home in the evening, and he is tipsy. His wife asks him:

"Where have you been?"

"Playing chess."

"Why do you smell of beer then?"

"What do you want me to smell of, chess?"

(www.forum-akm.net/viewtopic.php?Topic)

Jokes about drunkards are especially popular in communities with an ambivalent attitude towards alcohol - on the one hand, they consider it to be an important source of pleasure, and on the other hand, a serious social problem. Usually these texts make fun of both extremes: excessive drinking and total temperance (Davies 2011: 132-134). Polish jokes are a part of this pattern if we take into consideration the theme of drunkenness and the role of a woman (the drunkard's wife), but they break the pattern considering the small popularity of texts making fun of teetotallers.

\section{Parenthood}

An important group of Polish jokes are the ones about mothers. The motherfigure has an exceptional place in Polish culture. It is even said that a mother belongs to the sacred sphere, although when one wants to make the popular dirty word meaning 'prostitute' sound even more insulting, an old form of 'mother' mać - would be used to make it even stronger. To desecrate what is sacred is one of joke's attributes. So it is quite predictable that joketellers do not hesitate to make mothers the butts of their jokes.

Even though most jokes about mother do not belong to one strictly defined structural series, in some jokes the same initial formula is used. Some jokes begin with an expression: mamo ('mother') or mamusiu ('mummy'), repeated in some cases to underline its expressive character. In Polish jokes, it is mostly the mother who helps her child (usually a son, as boys appear six times more often in Polish jokes than girls) to do his homework and asks how it was at school.

"Mamo, dziś na lekcji pan od matematyki pochwalił mnie!” mówi Jasio.

"To bardzo tadnie, a co powiedziat?"

“Że wszyscy jesteśmy idiotami, a ja - największym!” 
"Mum, the mathematics teacher praised me today!" little Johnny says. "Oh, that's very nice. What did he say?"

"That we all are a bunch of idiots but I am the perfect one."

(Xięga Humoru 1999: 51)

Usually when the father is the one helping the child to do the homework, he becomes the butt of the jokes because of his incompetence.

Jasio odrabia zadanie domowe z geografii. W pewnej chwili pyta ojca:

“Tato, gdzie leża Batkany?”

"Mamy zapytaj. Ona robiła porzadki w szafie."

Jasio is doing his geography homework. He asks his father:

"Dad, where can we find the Balkans?"

"Ask your Mom. She was the one who cleaned the wardrobe."

(www.kawaly-o-jasiu.dimz.pl/rodzice2.html)

“Jasiu, masz dziś bardzo dobrze odrobione zadanie,” mówi nauczycielka.

“Czy jesteś pewien, ze twojemu tacie nikt nie pomagat?”

"Jasiu, your homework is very well done," the teacher says. "Are you sure nobody has helped your Dad?"

(http://wienmar.republika.pl/dowcipy.htm)

The trend to have a small number of children prevails. An average Polish family has one or two children only ${ }^{7}$. More than every fifth marriage is childless and every fourth child is born out of wedlock; teenage pregnancies also occur ${ }^{8}$.

Matka do córki:

"O której ty wracasz do domu!!! Ja w Twoim wieku...”

"Wiem, wiem," przerywa dziewczyna, "w ogóle nie wychodzitaś z domu bo ja miatam pięć miesięcy.”

A mother addresses her daughter:

"What time do you come back home?!!! When I was your age ..."

"I know," the daughter interrupts her, "you did not leave home at all, as

I was only five months old."

(http://www.webhumor.pl/kawaly-dowcipy/kobieta)

Infertility becomes a greater problem ${ }^{9}$ than it used to be but it is still rarely present in jokes.

7 Total fertility rate was 1,38 (in 2010) and natural increase was 0,3\% (in 2011); see http://www.stat.gov.pl/cps/rde/xbcr/gus/f_polska_w_liczbach_2012.pdf, last accessed on 2 June 2012.

8 http://wychowanie-dziecka.bloog.pl/id,328154952,title,Polska-rodzina-kondycja-rodziny-terminy-definicje-dane-statystyczne,index.html?ticaid=6e91c, last accessed on 19 May 2012.

9 http://www.familie.pl/artykul/Bezplodnosc-i-nieplodnosc-choroby-cywilizacyjne-XXIwieku,1069,1.htm; 23.09.2010, last accessed on 4 June 2012. 
Kobieta przychodzi do kliniki na zaptodnienie in vitro:

"Panie doktorze. Syn ma być silny jak Arnold Schwarzenegger, przystojny jak Leonardo DiCaprio i madry jak Einstein.”

Doktor kiwa głowa, daje jej środek nasenny, ściaga spodnie i zabiera się do dzieta, mruczac pod nosem:

"Ja ci dam Schwarzeneggera ..."

A woman comes to a clinic for in vitro impregnation:

"Doctor. I want my son to be as strong as Arnold Schwarzenegger, as handsome as Leonardo DiCaprio and as wise as Einstein."

The doctor nods his head, gives her a soporific drug, takes off his pants and sets to work murmuring:

"Schwarzenegger, my foot ..."

(http://dowcipy-o-kobietach.humoris.pl/dowcip/13432)

\section{Parents of adult children}

The relations between parents and children are very strong - and it does not matter how old the son or daughter is:

Chtopak pyta swoją dziewczynę:

"Opowiadasz o nas swojej mamie?"

"Coś ty! Mama o nic nie pyta. Za to mój mąż jest okropnie ciekawski."

A boy is asks his girlfriend:

"Do you tell your mother about us?"

"Come on! My mother is not asking about anything. But my husband is really inquisitive."

(Ale Jaja. O kobietach 12/97)

Przychodzi mama Jasia do biura pośrednictwa pracy, żeby synowi robote jaka zatatwić:

"Pani, nie bytoby dla Jasia jakieś roboty, bo pije chtopak i pije ..."

"A co Jasiu potrafi?"

"No murować umie, podstawówkę skończyt ..."

"A to mamy: murarz, 4000 na ręke..."

"Pani kochana! Toć przecié̇ Jasiu cały czas będzie chodzit pijany, jak tyle pieniędzy zarobi ... A za mniej coś nie ma?”

"No jest jeszcze - pomocnik murarza, 3000 na rękę..."

"No ale 3000? To przecież będzie pit i pit ... A tak za 600-700 ztotych to coś by się nie znalazło?”

“600-700 ... Hmmm ... To by Jasio musiat studia skończyć ...” 
Jasio's mother comes to an employment agency to fix her son a job:

"Madam, don't you have a job for my Jasio, the boy is drinking so much ..."

"And what can Jasio do?"

"Well, he can lay bricks, he has the primary school ..."

"Well, we have work for a brick layer here, PLN 4000 net ..."

"But madam! Jasio will be constantly drunk if he makes so much money

... Don't you have anything with smaller wages?"

"Well, there is a bricklayer's assistant, PLN 3000 net ...

"But 3000 ? He will be drinking heavily then ... And anything for PLN 600-700?"

"600-700 ... Hmmm ... Then Jasio would have to graduate from a university ..."

(www.dowcipy.jeja.pl/nowe,8,jasiu,26.html)

There is also a new, very popular cycle of jokes, present mainly on the Internet, which target mothers. They are known as "your old one" (Twoja stara) jokes. They are usually one-liners showing the stupidity or ugliness of the described women.

Twoja stara myje ptyn do naczyń :D

Twoja stara ma takie worki pod oczami, że nosi w nich kartofle.

Your old one washes the dishwashing liquid :D

Your old one has such bags under her eyes that she carries potatoes in them.

(http://www.kiermana.pl/88-1-twoja,stara.html\#axzz1xZ6VF7sy)

The subject of a twisted identity or gender appears more and more often in Polish jokes, though it is not a mainstream topic. It is present in the new cycle:

Raz, dwa, trzy twoja stara to TY.

One, two, three, your old one is YOU.

(http://www.kiermana.pl/88-1-twoja,stara.html\#axzz1xZ6VF7sy)

Twoja stara to ten prawej.

Your old one is the man on the right.

(http://www.kiermana.pl/88-1-twoja,stara.html\#axzz1xZ6VF7sy) 


\section{Dorota Brzozowska}

\section{Fathers}

Polish jokes confirm the results of the research on the linguistic picture of the world ${ }^{10}$, indicating that the most important aspect of the stereotype of a mother is her educative function, which is of great value, especially when the father's role becomes less and less important. Sociologists claim that the average Polish family has ceased to be patriarchal, and very often children are brought up almost exclusively by mothers. Fathers' share in upbringing children is minimal if any. Recent publications in Poland prove the significance of this problem and the growing awareness of the generation "betrayed by their fathers" (Eichelberger 1998).

“Żona zarzuca mi, że nie troszczę się o dzieci. To jest nie do zniesienia!”

"A ile ma pan dzieci?"

"Dwoje.. A może troje?"

"My wife claims I don't take care of my children. I can't stand it any longer!"

"How many children have you got?"

"Two ... or maybe three?"

(Coś z dowcipami. O facetach 11/97)

The study of stereotypes underlines the differences between the sets of connotations tied to the images of mothers and fathers (Panasiuk 1998). The results show that we associate kindness and love with mother, whereas money, discipline and work with father. On the other hand, Polish fathers are caring. They like playing with their children and want to spend as much time with them as possible. This is not welcome by their bosses who do not allow them to leave work before 4 p.m. and do not treat applications for paternity leaves too

\footnotetext{
${ }^{10}$ One of the best developing and biggest linguistic schools in Poland is the Lublin school established by Professor Jerzy Bartmiński, which deals with the study of the linguistic picture of the world. The Lublin ethnolinguistic school belongs to the field of anthropological and cognitive linguistics. Its origin can be seen in dialectology and folklore studies, although from the very beginning of its existence it drew on the inspiration of the anthropological cultural linguistics. The research comprised the Polish folk language, the language and poetics of folk texts, the Polish language in general, the colloquial language and its internal diversification. They take into account the comparative, intralinguistic and intracultural aspects. One of the research methods in this school is profiling. In the approach which differs slightly from Langacker's study and which is advocated by Jerzy Bartmiński and his co-workers, it is perceived as "a way of presenting an object from various perspectives, the notion's forming depending on how a particular subject refers to it". Profiles are "variants of meaning relativized subjectively, they arise from the subjective conceptualization of the same object" (Bartmiński 1993: 272).
} 
seriously. Polish fathers frequently work overtime, too, and as a result they spend with their children only 53 minutes daily ${ }^{11}$.

\section{Children}

One of the series of jokes picturing the relation between mothers and sons is the one about handicapped Jasio, presenting the mother as siding with her child and being eager to lie to him about his condition to make him feel good and healthy, but betraying herself by making him do strange things:

Przychodzi Jasio do domu i mówi:

"Mamo, wszyscy się ze mnie śmieja i mówia, że mam duże uszy!"

"Nie masz, synku, ale idź na dach i nadstuchuj, czy tato jeszcze nie wraca z Paryża."

Jasio comes home and tells his mother:

"Mom, everyone is laughing at me and telling me that I have large ears!"

"You do not, son, but do go up to the roof and listen out for your Dad coming back from Paris."

(Dobry Humor. O kurach 8/1996)

When we consider the children's names in jokes, we can notice that in Polish jokes they are not very diversified. The most frequently used boy's name is Jaś, Jasio (Johnny). Other boy's names are Kazio, Jacek, Tomek. Sporadically, a girl's name is used - it is usually Kasia. Most frequently, however, the joke's protagonist is the nameless son, little son or boy.

\section{Mothers-in-law}

Jokes confirm the common belief that the stereotype of a mother is opposed to the one of a stepmother and a mother-in-law. The latter image stereotypes are highly negative. Strangeness and hostility are the dominant features in them (Bartmiński 1998). The connotations of the term mother-in-law are that she is a witch, wicked, snooper. The picture of a father-in-law is much more positive and it is connoted with such words as good, hen-pecked husband, father and serenity (Panasiuk 1998). There are no jokes about fathers-in-law, but there are plenty of jokes about mothers-in-law and they deal with the mother of the

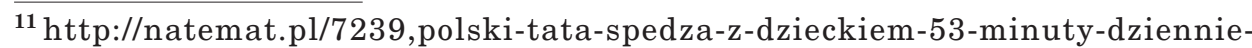
chce-wiecej-ale-szefowie-smieja-sie-z-urlopow-tacierzynskich, "Gazeta Wyborcza", 26.04.2012, last accessed on 4 June 2012.
} 
women. This cycle could be interpreted in favour of the thesis of male domination in joke creation.

The common feature of jokes about mothers-in-law is connected with their semantically characteristic aggressiveness. They are usually the manifestation of male solidarity. If a man happens to appreciate his mother-in-law, he becomes very quickly convinced by his fellows that he is absolutely wrong:

Na posterunku policji dzwoni telefon:

"Ratunku, moja teściowa chce wyskoczyć przez okno!” krzyczy gtos w stuchawce.

"A co, okno się zacięto i nie może go pan otworzyć?" domyśla się życzliwie policjant.

A telephone is ringing at a police station:

"Help, my mother-in-law wants to jump out of the window!" the man on the phone shouts.

"So what? Has the window jammed and can't you open it?" asks the policeman kindly.

(Humor o teściowej 8/93: 27)

A large proportion of Polish mother-in-law jokes may be found on the Internet. They are mainly examples of dark humour, and they are not much different from what they used to be a decade ago.

Idzie Masztalski z obita, sinq buźkq i taszczy duże walizki. Spotyka przyjaciela:

"Co Ci się stato Masztalski?"

"A, teściowa mnie pobiła."

"Jak by mnie tak teściowa pobita, to bym ja chyba poćwiartowat!"

"A ty myślisz, że co ja tu dźwigam w tych walizach?"

Mr Masztalski looks beaten, blue in the face and carries heavy suitcases.

He meets his friend.

"What's happened?"

"My mother-in-law has beaten me up."

"If mine had I would have cut her into pieces!"

"And what do you think I'm carrying in these suitcases?"

(www.pol.pl/humor)

The mother-in-law is perceived in jokes as the major enemy of the family and the person who is a serious threat to the family's happiness and an object of intense aggression. This group of jokes was traditionally popular when there was a housing problem and young couples were forced to live with their parents. In recent years the social and economic situation has changed in this matter, and 
more couples are able to live on their own, so the group of jokes is still present in collective memory and on the websites, but it is not very productive any more ${ }^{12}$.

\section{Chores}

In Polish culture the feminine role has been traditionally strictly connected with being at home as a housewife responsible for all kinds of housework. One of women's many duties is the preparation of food, seen for ages as a good way of showing care and good feelings towards other family members. This belief is accompanied by numerous jokes in which women prepare the meals:

“Co ci zrobiła żona, że ją tak strasznie zwymyślałeś?”

“Jak to co?! Obiad!”

"What did your wife do when you thundered at her in such a way?"

"She's made dinner! What else?!"

(Coś z dowcipami. O facetach 11/12, 1997)

The prepared food is usually said to be of bad quality:

"Co dostanę, jeśli codziennie będę ci gotować takie pyszne obiady jak dziś?"

"Najpóźniej za trzy lata sto milionów złotych z tytułu mojego ubezpieczenia na życie...”

After dinner, a young wife asks her husband: "What will I get if I cook such delicious dinners for you every day?"

"A hundred million zlotys from my life insurance company in three years at the latest."

(100 Dowcipów na każdą okazję 2/97)

Food is in the centre of family life. Not only is eating together treated as the best quality time when the family can talk and share their everyday experiences, but also because a stereotypical Polish mother is constantly worried about her children not eating enough.

Zdenerwowana mama do córeczki:

"Wiesz co się dzieje z matymi dziewczynkami, które nie zjadają wszystkiego z talerza?!”

"Wiem, pozostaja szczupte, zostają modelkami i zarabiają kupę forsy ...”

\footnotetext{
${ }^{12}$ Almost half of the young people (48.3\%) claim that they are satisfied with their living conditions although they would expect to have better mortgage credit possibilities or some other financial support to build their own houses or buy new apartments (http:// zds.kprm.gov.pl/sites/default/files/mlodzi_2011_06.pdf, last accessed on 2 June 2012).
} 
An angry mother addresses her daughter:

"Do you know what happens to little girls who do not eat everything from their plates?!"

"I do, they remain slim, become models and make loads of money ..." (http://wienmar.republika.pl/dowcipy.htm)

A significant part of society still claims that women should be responsible also for all the housework. Although women who have full-time jobs work fewer hours at home than typical housewives, they spend much more time doing the chores than their husbands. Nowadays the life of many families differs from the traditional model of a husband who earns a living and a wife who spends her day doing housework and taking care of their two children. But the changes in society have not brought about changes in the stereotypes - or jokes - so far. Men are seen in the context of their public lives and professional jobs, while women are depicted in the private spheres of family lives. Many adult Poles still claim that a woman can be happy only at home ${ }^{13}$.

"Dlaczego soltys kupit żonie samochód bez silnika?"

"Bo uważa, $\dot{z}$ e miejsce kobiety jest $w$ domu!"

"Why did the head of the village buy his wife a car without an engine?"

"Because he thinks the woman's place is at home!"

(www.pol.pl/humor)

\section{Public sphere}

Women are hardly ever pictured in their working places; if so, they work at hospitals, offices or schools doing the lowest paid jobs such as cleaning, nursing or teaching.

Jokes about teachers are the most numerous; female teachers frequently play a supporting role in them while the main protagonist of the events taking place at school is the pupil:

Nauczycielka narysowata na tablicy trójkąt bez jednego boku.

"Jasiu,” pyta, "czego brakuje w tym trójkacie?”

"Kredy!"

A teacher has drawn a triangle without one side on the blackboard.

"Jasiu, - what is missing in this triangle?" she asks.

"Chalk!"

(Coś z dowcipami. O facetach 11/97)

\footnotetext{
${ }^{13}$ Urszula Nowakowska, Emilia Piwnik, Kobiety w rodzinie, http://temida.free.ngo.pl/ raprodzina.htm, last accessed on 2 June 2012.
} 
A working woman can be a housekeeper, a nanny, a hospital attendant, an assistant, a cashier, a shop assistant and a cleaner in jokes. The amount of jokes about working women is quite small given the significance of women's work in the society's life. Working women in jokes are usually lazy, stupid, naive and clumsy.

Dyrektor przyjmuje kandydatkę do pracy. Oświadcza, że stanowisko może być powierzone tylko osobie odpowiedzialnej.

“Co do tego może pan być zupetnie spokojny,” odpowiada dziewczyna.

“Tam, gdzie pracowatam do tej pory, za kazdym razem, gdy coś nie wychodziło, mówiono, że ja jestem odpowiedzialna.”

The manager employs a woman. He tells her that this position can only be taken by a responsible person.

"You may be absolutely certain of this," the girl answers him. "In all the places I have worked so far, whenever something was wrong they said I was responsible."

(100 Dnko 7/97)

Women working as secretaries are often pictured as being the bosses' mistresses.

Rozmawia dwóch dyrektorów:

"Podobno masz nowa sekretarkę?” - "Owszem.” - "I jesteś z niej zadowolony?" - "Po pierwszym dniu trudno powiedzieć ...” - "Młoda, tadna?” - "Taka sobie ...” - "A jak się ubiera?” - "Bardzo szybko."

Two managers are talking:

"They say you have a new secretary?" - "I do." - "And are you satisfied with her?" - "It is difficult to say after just one day ..." - "Is she young and pretty?" - "Quite ..." - "And how does she dress?" - "Very quickly." (http://sekretarki.dowcipy.pl/)

\section{Free time activities}

There are about $5 \%$ of jokes presenting women during their free time activities, which stereotypically are none other than gossiping, shopping and watching TV. Women in such jokes do not participate in sports events or parties, and they are frequently regarded by men as being less important than such events:

“Ważniejszy ci ode mnie mecz piłki nożnej!” - złości się żona.

"Wybacz, kochanie - wzdycha mą̇ - ale i rozgrywki w koszykówce. "No $i$ boks," dorzuca po chwili. 
"A football match is more important for you than I am!" a wife complains. "I am sorry, my dear," her husband sighs, "but so are basketball games." "Well, and boxing as well," he adds later. (http://humor.pl/kobieta_i_mezczyzna/708)

Similarly, it is usually men who can take the opportunity to relax at home in front of the TV set, preferring this to showing any interest in their wives and children. The following jokes present the destructive influence of TV on family life:

Rozmawiaja dwa przedszkolaki:

"Mój tatuś bawi się ze mną!"

"Mój te $\dot{z}$, ale tylko wtedy gdy jest zepsuty telewizor."

Two kindergarten kids are talking:

"My dad plays with me!"

"My dad plays with me, too, but only when the TV set is out of order."

(Dobry Humor. O telewizji 12/1998)

Shopping is a common way of spending one's free time. The Polish society is becoming more and more consumption-oriented. Shopping has stopped being purely functional or material, and has become symbolical, defining a man's place in the world and determining his core identity, and becoming an important hobby ${ }^{14}$. In jokes about women shopping, they are doing it at their husbands' expense or at least with their consent:

Szatnia w taźni. Na wieszakach wisza ubrania. W pewnym momencie $w$ jednym z nich dzwoni telefon komórkowy. Rozbierający się obok mężczyzna wyciaga komórkę: "Cześć kochanie, o co chodzi?” - "[...]” - "A ile to futro kosztuje? 5000? Trochę drogo, ale dobrze, kup sobie.”

Po zakończeniu rozmowy facet bierze komórkę $i$ wchodzi do pomieszczenia taźni. Już od drzwi woła: "Chtopaki, czyj to telefon?"

A locker room in a bath house. Clothes are hanging all over the hangers. Suddenly in one of them a mobile phone rings. A man getting undressed answers the phone: "Hi, darling, what's up?" - "[...]" - "And how much is the fur? 5000? A bit expensive, but you may buy it."

Having ended the conversation he takes the phone and enters the bath house. He calls out: "Boys, whose phone is it?"

(http://www.dowcipy.org/d_roz.php)

\footnotetext{
${ }^{14}$ One of the newest social problems is Compulsive Shopping Addiction - Shopoholism that concerns both men and women, see http://www.uzaleznienia.info/index.php?option=com content\&view=article\&id=68: natrectwo-kupowania\&catid=15\&Itemid=122, accessed 2.06.2012. The analysis of the contemporary women's patterns of consumption can be found in: Dorota Nowalska, Rekonstrukcja wzorów zachowań konsumpcyjnych wśród kobiet na przykładzie województwa śląskiego, 2007, Uniwersytet Śląski, http://www. sbc.org.pl/Content/4452/doktorat2693.pdf, accessed on 2 June 2012.
} 


\section{Conclusions}

In the majority of jokes, women are still pictured in their family as wives, lovers, mothers and mothers-in-law. The most common scripts of the jokes are wives' and lovers' infidelity. Generally speaking, the sex / no sex opposition dominates in these types of jokes. Jokes about mothers reveal women's care while motherin-law jokes presuppose hatred and fear. Women in jokes do most household chores (especially cooking and cleaning) and take most of the responsibility for children. It is mainly the mother who helps her child, usually a son. Adult daughters more often appear with their mothers than with their fathers and share negative opinions about men with their mothers.

Jokes about Polish mothers are traditionally outnumbered by jokes about mothers-in-law. Their common feature is connected with their semantically characteristic aggressiveness. Women in jokes not only have lovers but are also responsible for broken marriages, so there is a significant number of jokes about divorces. Most often, though, wives are pictured as angry spouses of their drunkard husbands. Polish men meet in bars and after coming back home they try to find excuses and prove their innocence, and ultimately suffer because of the furious wives.

Women are hardly ever pictured in their working place (see also Laineste 2012). The changes in society have not altered the stereotypes so far and still men are seen in the context of their public lives and professional jobs, while women are shown in the private spheres of family lives.

The analysis of jokes in Poland shows that some groups have become petrified (as the mother-in-law cycle) and some new jokes have appeared, dealing with new subjects such as aggression toward someone else's mothers. Surprisingly, there are no jokes about the paternal leave which was recently introduced and wildly discussed in the media, and there are also no jokes about women drinking alcohol, although this problem exists in the society, which is more and more permissive towards women drinking in public places. The jokes about family do not deal with all the "hot" subjects. They have remained mostly traditional with certain recurring cycles being at the core of the Polish cultural heritage - not very productive, but still present. 


\section{Dorota Brzozowska}

\section{References}

Bartmiński, Jerzy 1993. O profilowaniu i profilach raz jeszcze. [On profiling and profiles.] In: J. Bartmiński \& R. Tokarski (eds.) O definicjach i definiowaniu. [On definitions and defining.] Lublin: Wydawnictwo UMCS, pp. 269-275.

Bartmiński, Jerzy 1998. Podstawy lingwistycznych badań nad stereotypem - na przykładzie stereotypu matki. [Fundamentals of linguistic research on stereotypes: The stereotype of the mother.] In: J. Anusiewicz \& J. Bartmiński (eds.) Stereotyp jako przedmiot lingwistyki. Teoria, metodologia, analizy empiryczne, Vol. 12. [Stereotype as a subject for linguistic research. Theory, methodology, empirical analysis.] Wrocław: Towarzystwo Przyjaciół Polonistyki Wrocławskiej, pp. 63-83.

Brzozowska, Dorota 2003. Jokes about women in Poland. In: M. Ž. Čarkić (ed.) Stil 2 [Style.] Belgrad: The International Association Style, pp. 283-293. Available at http:// www.rastko.rs/filologija/stil/2003/20Brzozowska.pdf, last accessed on 5 June 2012.

Brzozowska, Dorota 2008. Polish jokes about Jewish women. In: A. Kwiatkowska \& S. Dżereń-Głowacka (eds.) Shades of Humor. Humor: Theories, Applications, Practices, Vol. 1/2. Piotrków Trybunalski: Naukowe Wydawnictwo Piotrkowskie, pp. 149-157.

Brzozowska, Dorota 2008. Polski dowcip etniczny. Stereotyp a tożsamość. [Polish ethnic jokes. Stereotypes and identity.] Opole: Wydawnictwo Uniwersytetu Opolskiego.

Brzozowska, Dorota 2009. Polish jokelore in the period of transition. In: A. Krikmann \& L. Laineste (eds.) Permitted Laughter: Socialist, Post-socialist and Never-socialist Humour. Tartu: ELM Scholarly Press, pp. 127-169.

Davies, Christie 1990. An explanation of Jewish jokes about Jewish women. Humor: International Journal for Humor Research, No 3-4, pp. 363-378.

Davies, Christie 2002. The Mirth of Nations. New Brunswick, London.

Davies, Christie 2011. Jokes and targets. Bloomington: Indiana Univesity Press.

Eichelberger, Wojciech 1998. Zdradzony przez ojca. [Betrayed by his father.] Warszawa: Wydawnictwo DO.

Jędrzejko, Ewa 1994. Kobieta w przysłowiach, aforyzmach i anegdotach polskich. Konotacje i stereotypy. [Women in Polish proverbs, aphorisms and anecdotes. Connotations and stereotypes.] In: J. Anusiewicz \& K. Handke (eds.) Język a kultura. Pteć w języku $i$ kulturze, Vol. 9. [Language and culture. Gender in language and culture.] Wrocław: Wiedza i Kultura, pp. 159-172.

Laineste, Liisi 2012. Women in Estonian jokes. In: L. Laineste \& D. Brzozowska \& W. Chłopicki (eds.) Estonia and Poland. Creativity and tradition in cultural communication, Vol. 1. Tartu: ELM Scholarly Press, pp. 33-52.

Nęcki, Zbigniew 2000. Komunikacja międzyludzka. [Interpersonal communication.] Kraków: Antykwa.

Nowalska, Dorota 2007. Rekonstrukcja wzorów zachowań konsumpcyjnych wśród kobiet na przyktadzie województwa śląskiego. [Reconstruction of consumer behavior patterns among women in the Silesian region.] Uniwersytet Śląski. http://www.sbc.org.pl/Content/4452/doktorat2693.pdf, last accessed on 2 June 2012. 
Panasiuk, Jolanta 1998. O zmienności stereotypów. [The variation of stereotypes.] In: J. Anusiewicz \& J. Bartmiński (eds.) Stereotyp jako przedmiot lingwistyki. Teoria, metodologia, analizy empiryczne, Vol. 12. [Stereotype as a subject for linguistic research. Theory, methodology, empirical analysis.] Wrocław: Towarzystwo Przyjaciół Polonistyki Wrocławskiej, pp. 84-98.

Raskin, Victor 1985. Semantic mechanisms of humor. Dordrecht: Reidel Publishing Company.

Szukalski, Piotr 2011. Matżeństwa powtórne w powojennej Polsce. [Re-marriage in postwar Poland.] Wiadomości Statystyczne, No. 4, pp. 11-22. http://www.stat.gov.pl/cps/rde/ xbcr/pts/oz_wiadomosci_statystyczne_4_2011.pdf, last accessed on 5 June 2012.

\section{Sources}

\section{A. Different issues of periodicals with jokes (1995-1998)}

Dowcip za dychę. [Jokes for a tenner.] Warszawa: Naja-press.

Humor [Humour]; Humor Szkolny [School humour]; Śmiechu Warte. Wybór najlepszych dowcipów z prasy humorystyczno-satyrycznej. [Laughable. Best jokes from humorous press.] Warszawa: K.M.S.O. Sp. z o.o..

Najlepsze Dowcipy. Ogólnopolski miesięcznik humoru. [Best jokes. Polish humor magazine.] Koszalin.

Super Dowcipy [Super jokes]; Dowcip Miesiaca [Joke of the month]; Dobry Humor. [Good humour.] O kurach 8/1996 [About hens]; O telewizji 12/1998 [About TV]; 103 Najlepsze Dowcipy. [103 best jokes.] Superpress.

Świeże Dowcipy Prosto z Komputera [Fresh jokes straight from your computer]; Coś z dowcipami. [About jokes.] O facetach 11/97 [About the guys]; Ale Jaja. O kobietach 12/97 [But the eggs. About women]. Warszawa: Podulkastudio.

100 Dnko - 100 Dowcipów na każda okazję. [100 jokes for every occasion.] Warszawa.

Humor matżeński. [Jokes about marriage.] Humor Kieszonkowy 6/96. Warszawa: Infopress.

Humor o teściowej. [Jokes about mothers-in-law.] Zamek 8/93.

\section{B. Books with collections of jokes}

Hącia, Agata (ed.). Humor polski. [Polish humour.] Warszawa: Świat Książki, 2003.

Pektyn, Andrzej \& Pettyn, Remigiusz (eds.). Wielka księga anegdot. [Great book of anecdotes.] Warszawa: Europa, 1998.

Sieradzcy, Andrzej \& Sieradzcy, Grażyna (eds.). Wielka księga humoru polskiego. [Great book of Polish humour.] Warszawa: Ethos, 2000.

Mondel, Dorota \& Skierkowski, Marek (eds.). Xsięga humoru. [Book of humour.] Wrocław: FOX, 1999. 


\section{Dorota Brzozowska}

\section{Websites (1995-2012)}

http://alejaja.pl/, last accessed on 4 June 2012.

http://dowcipy-o-kobietach.humoris.pl, last accessed on 4 June 2012.

http://sekretarki.dowcipy.pl, last accessed on 4 June 2012.

http://wienmar.republika.pl/dowcipy.htm, last accessed on 4 June 2012.

http://www.dowcipy.celebs.pl, last accessed on 4 June 2012.

http://www.dowcipy.jeja.pl, last accessed on 4 June 2012.

http://www.dowcipy.net.pl, last accessed on 4 June 2012.

http://www.dowcipy.org, last accessed on 4 June 2012.

http://www.duzohumoru.pl/kawaly, last accessed on 4 June 2012.

http://www.forum-akm.net/viewtopic, last accessed on 1 April 2012.

http://www.humorki.pl/p_zagadki.php, last accessed on 4 June 2012.

http://www.joemonster.org, last accessed on 4 June 2012.

http://www.kawaly-o-jasiu.dimz.pl/rodzice2, last accessed on 4 June 2012.

http://www.kiermana.pl/88-1-twoja,stara.html\#axzz1xZ6VF7sy, last accessed on 26 April 2012.

http://www.pol.pl/humor, last accessed on 6 October 2007.

http://www.rechot.com/index.php, last accessed on 4 June 2012.

http://www.sadurski.com/gify, last accessed on 4 June 2012.

http://www.webhumor.pl/kawaly-dowcipy/kobieta, last accessed on 4 June 2012.

http://humor.pl/kobieta_i_mezczyzna/708, last accessed on 12 June 2012. 